Vol. 1 No. 3 Desember 2021, p-2797-5592 | e-2797-5606

\title{
SUPERVISI AKADEMIK UNTUK MENINGKATKAN KREATIVITAS GURU \\ DALAM KEGIATAN BELAJAR MENGAJAR (KBM) DI MASA PANDEMI COVID-19 MELALUI PEMBELAJARAN DARING
}

\author{
PESRA DARYANTI \\ SMPN 47 Batam \\ Email : pesradaryanti47@gmail.com
}

\begin{abstract}
ABSTRAK
Tujuan Penelitian Tindakan Sekolah yang dilaksanakan di SMP Negeri 47 Kota Batam adalah mengupayakan supervisi akademik untuk meningkatkan kreativitas guru dalam melaksanakan kegiatan belajar mengajar (KBM) di masa pandemi Covid-19 melalui pembelajaran daring. Penelitian ini dilakukan terhadap 9 orang subjek penelitian. Penelitian dilakukan dalam dua siklus yang masing-masing siklusnya dilakukan dengan tahapan perencanaan, pelaksanaan, observasi dan refleksi. Metode pengumpulan data yang digunakan adalah observasi dan untuk menganalisis datanya digunakan analisis deskriptif kuantitatif. Dilihat dari hasil observasi yang telah dilakukan kreativitas guru mengalami peningkatan dari nilai rata-rata awal sebesar 74,89 kategori Cukup (C) dengan prosentase 22,22\%, siklus I meningkat menjadi 84 kategori Baik (B) dengan prosentase 44,44\%, dan siklus II meningkat menjadi 93,33 kategori Amat Baik (A) dengan prosentase $88,89 \%$. Dengan demikian dapat disampaikan simpulan bahwa supervisi akademik yang diterapkan peneliti telah mampu meningkatkan kreativitas guru dalam melaksanakan kegiatan belajar mengajar (KBM) di masa pandemi Covid-19 pada semester I tahun pelajaran 2020/2021 SMP Negeri 47 Kota Batam.
\end{abstract}

Kata kunci: Supervisi Akademik, Kreativitas Guru, Kegiatan Belajar Mengajar (KBM), Pandemi Covid-19, Pembelajaran Daring.

\section{ABSTRACT}

The purpose of the School Action Research conducted at SMP Negeri 47 Batam City is to seek academic supervision to increase teacher creativity in carrying out teaching and learning activities (KBM) during the Covid-19 pandemic through online learning. This research was conducted on 9 research subjects. The research was conducted in two cycles, each cycle carried out with stages of planning, implementation, observation and reflection. The data collection method used was observation and to analyze the data used quantitative descriptive analysis. Judging from the observations that have been made, the creativity of teachers has increased from the initial average value of 74.89 category Enough (C) with a percentage of $22.22 \%$, cycle I increased to 84 categories Good (B) with a percentage of $44.44 \%$, and the second cycle increased to 93.33 category Very Good (A) with a percentage of $88.89 \%$. Thus, it can be concluded that the academic supervision applied by researchers has been able to increase teacher creativity in carrying out teaching and learning activities (KBM) during the Covid-19 pandemic in the first semester of the 2020/2021 academic year at SMP Negeri 47 Batam City. Keywords: Academic Supervision, Teacher Creativity, Teaching and Learning Activities

(KBM), Covid-19 Pandemic, Online Learning.

\section{PENDAHULUAN}

Menteri Pendidikan dan Kebudayaan Republik Indonesia mengeluarkan Surat Edaran Nomor 4 Tahun 2020 Tentang Pelaksanaan Kebijakan Pendidikan Dalam Masa Darurat Penyebaran COVID-19, dalam Surat Edaran tersebut dijelaskan bahwa proses belajar dilaksanakan di rumah melalui pembelajaran daring/ jarak jauh untuk memberikan pengalaman belajar yang bermakna bagi siswa melalui pertemuan virtual atau pertemuan yang sangat berguna, yang sangat membantu walaupun tidak bertemu langsung.

Guru-guru mesti melaksanakan hal diatas dikarenakan kegiatan belajar mengajar (KBM) secara tatap muka yang biasa dilakukan di sekolah dianggap mampu meningkatkan 
penyebaran covid-19, untuk itu penggunaan teknologi digital dapat memungkinkan siswa dan guru melaksanakan proses pembelajaran walaupun berada ditempat yang berbeda sehingga kontak fisik secara langsung dapat dihindari. Menurut Moore, Dickson-Deane, \& Galyen (dalam Sadikin, 2020:214) pembelajaran daring merupakan pembelajaran yang menggunakan jaringan internet dengan aksesibilitas, konektivitas, fleksibilitas, dan kemampuan untuk memunculkan berbagai jenis interaksi pembelajaran.

Pelaksanaan pembelajaran daring ini memerlukan dukungan perangkat-perangkat mobile seperti smartphone atau telepon android, laptop, komputer, tablet, maupun iphone yang dilengkap berbagai aplikasi sehingga dapat dipergunakan oleh guru dan siswa untuk melaksanakan pembelajaran jarak jauh serta mengakses informasi kapan saja dan dimana saja. Dengan adanya kebijakan tersebut besar harapan pemerintah agar guru memiliki kreativitas yang tinggi dalam mengemas pembelajaran sebaik dan semenarik mungkin meskipun kegiatan belajar mengajar dilaksanakan dalam jarak jauh, karena pada dasarnya salah satu nilai keunggulan yang harus dimiliki oleh guru adalah kreativitas.

Samiun (dalam Indayani, 2002: 13) menyebutkan kreatifitas adalah "kemampuan untuk membuat kombinasi-kombinasi baru/melihat hubungan-hubungan baru di antara unsur data atau hal-hal yang sudah ada sebelumnya". Menurut Nana Syaodih (2009:104) kreativitas merupakan kemampuan yang dimiliki seseorang untuk menemukan dan menciptakan sesuatu hal baru, cara-cara baru, model baru yang berguna bagi dirinya dan bagi masyarakat. Hal baru itu tidak perlu selalu sesuatu yang sama sekali tidak pernah ada sebelumnya, unsur-unsurnya mungkin telah ada sebelumnya, tetapi individu menemukan kombinasi baru, hubungan baru, konstruk baru yang memiliki kualitas yang berbeda dengan keadaan sebelumnya. Seorang yang kreatif adalah orang yang memiliki ciri-ciri kepribadian tertentu seperti: mandiri, bertanggung jawab, bekerja keras, motivasi tinggi, optimis, punya rasa ingin tahu yang besar, percaya diri, terbuka, memiliki toleransi, kaya akan pemikiran dll (Nana Syaodih, 2009:104).

Pendapat lain dikemukakan oleh A. Chaedar Alwasilah (dalam Ngainun,2009:245) yang menjelaskan bahwa kreativitas adalah kemampuan mewujudkan bentuk baru, struktur kognitif baru, yang mungkin bersifat fisikal seperti teknologi atau bersifat simbolik dan abstrak seperti defenisi, karya sastra, atau lukisan.

Dari beberapa pendapat diatas, maka yang dimaksud dengan kreativitas adalah ciri khas kepribadian yang dimiliki individu yang menandai kemampuan untuk mengekspresikan dan mewujudkan potensi daya berpikir sehingga dapat menghasilkan sesuatu (produk) yang baru dan unik melalui proses serta adanya faktor pendorong. Berdasarkan pemaparan dari beberapa pendapat ahli, maka yang dimaksud dengan kreativitas guru adalah kepribadian khas yang dimiliki guru yang mendukung proses pembelajaran untuk menghasilkan sesuatu (produk) yang baru dan unik sebagai wujud kemampuan berpikir yang tidak terlepas dari faktor-faktor pendorong.

Kreativitas guru merupakan kemampuan seorang guru untuk mengekpresikan dan mewujudkan potensi daya pikirnya dalam menghasilkan sesuatu yang baru dan unik atau kemampuan mengkombinasikan dan menvariasikan sesuatu yang sudah ada atau menjadi sesuatu yang lain agar menarik. Kreativitas guru yang diharapkan adalah agar guru menciptakan kegiatan belajar mengajar dengan beragam cara yang digunakan sehingga tujuan pembelajaran dapat tercapai, salah satunya dengan memanfaatkan kemajuan teknologi yang didukung oleh jaringan internet. Melalui pembelajaran daring pemerintah berharap agar guru dapat berinteraksi dengan siswa menggunakan beberapa aplikasi internet sebagai wujud kreativitas guru dalam melakukan inovasi pendidikan untuk menjawab tantangan akan ketersediaan sumber belajar yang variatif.

Sayang nya, harapan tersebut tidak sesuai dengan kenyataan yang ada di lapangan. Beberapa guru terlihat kesulitan menyesuaian diri dengan kebijakan yang ada yaitu melaksanakan kegiatan belajar mengajar melalui pembelajaran daring. Ini menandakan bahwa kreativitas guru masih rendah. Ini terlihat dari fakta dilapangan yaitu sesuai hasil observasi yang dilakukan pada guru-guru di SMP Negeri 47 Kota Batam. Hasil yang diperoleh adalah 
kreativitas guru dalam melaksanakan kegiatan belajar mengajar melalui pembelajaran daring kurang optimal, karena masih dalam kategori $C$ (cukup) dengan nilai rata-rata 74,89. Adapun yang menjadi kelemahan-kelemahan guru adalah: 1) guru masih gagap teknologi, 2), guru masih berpatokan pada cara pembelajaran konvensional dan jarang mau melakukan sesuatu hal yang baru, 3) guru masih kesulitan dalam memilih dan menggunakan aplikasi yang tepat dalam pembelajaran daring, 4) Guru kesulitan menyajikan materi pelajaran melalui pembelajaran daring, 5) Guru kesulitan mengatasi kendala-kendala yang disebabkan oleh jaringan.

Berdasarkan beberapa kelemahan guru tersebut, diketahui pula beberapa penyebab kelemahan itu terjadi sehingga kreativitas guru masih tergolong rendah. Adapun penyebabpenyebab tersebut antara lain: 1) rasa ingin tahu guru terhadap kemajuan teknologi yang ada masih sangat rendah, 2) guru tidak mau terbuka terhadap pengalaman baru, 3) guru belum memiliki pemahaman yang baik terhadap aplikasi-aplikasi baru, 4) Guru terbiasa melaksanakan pembelajaran dengan berceramah tatap muka sehingga media yang digunakan kurang bervariasi, 5) Pemahaman guru mengenai jaringan internet masih terbatas.

Apabila hal tersebut dibiarkan secara terus-menerus, akan mengakibatkan kegiatan belajar mengajar secara daring tidak dapat terlaksana dengan baik. Untuk itu peneliti meny adari betapa pentingnya kreativitas guru dalam melaksanakan kegiatan belajar mengajar di masa pandemi covid-19 ini. Oleh karenanya peneliti sebagai Kepala Sekolah mesti giat mengecek dan mengupayakan peningkatan kualitas guru-guru salah satunya adalah kreativitas guru yang dirasa masih bisa ditingkatkan lagi.

Supervisi akademik peneliti upayakan guna meningkatkan kreativitas guru dalam melaksanakan kegiatan belajar mengajar dimasa pandemi ini. Supervisi akademik adalah serangkaian kegiatan untuk membantu guru mengembangkan kemampuannya mengelola proses pembelajaran demi pencapaian tujuan pembelajaran (Glickman dalam Depdiknas, 2009 : 10). Sedangkan menurut Daresh 1989 (dalam Martiyono, 2014:99) supervisi akademik adalah serangkaian kegiatan untuk membantu guru mengembangkan kemampuannya mengelola proses pembelajaran demi pencapaian tujuan pembelajaran. Supervisi akademik merupakan upaya membantu guru-guru mengembangkan kemampuannya mencapai tujuan pembelajaran.

Fakta dilapangan menunjukan kondisi siswa SMP Negeri 47 Batam umumnya berasal dari kalangan masyarakat rural di wilayah pinggir kota. Mata pencaharian utama orang tua sebagian besar adalah buruh pabrik dan pekerja lepas. Hal tersebut menjadi kendala bagi siswa dan orang tua dalam menerapkan pembelajaran daring. Sebagian besar pembelajaran dilakukan menggunakan gawai untuk menyampaikan bahan ajar dan tugas, sedangkan sebagian besar dari orang tua menggunakan gawai untuk keperluan kerja. Hanya sebagian kecil siswa yang telah memiliki gawai pribadi. Bahkan, terdapat juga sebagian kecil orang tua siswa yang masih menggunakan gawai yang belum mendukung akses internet. Begitu juga siswa dan orang tua siswa umumnya memiliki pemahaman yang kurang terhadap penggunaan teknologi pendidikan melalui aplikasi-aplikasi yang dipasangkan pada gawai. Para siswa dan orang tua siswa agaknya cenderung terbiasa menggunakan gawai untuk keperluan telekomunikasi atau multimedia. Penggunaan aplikasi pendidikan daring perlu disosialisasikan agar dapat memperlancar proses belajar siswa. Kendala sinyal hilang atau tidak stabil pun sering terjadi. Hal ini umumnya dialami juga oleh siswa-siswa di daerah lain (Anugrahana, 2020:282).

Di sisi lain, guru di SMP Negeri 47 Batam masih terdapat guru-guru yang cenderung tidak dapat mengoperasikan gawai dan perangkat komputer dengan lancar. Kondisi yang demikian membatasi guru dalam mengelola pembelajaran secara daring. Guru yang berusia kurang dari 45 tahun pun juga mengalami kesulitan karena terbiasa melakukan pembelajaran secara tatap muka. Adanya instruksi pemerintah terkait pembelajaran daring mengharuskan semua guru, mau tidak mau, untuk menyesuaikan diri agar tujuan pendidikan dapat tetap tercapai. Pembelajaran harus tetap dilaksanakan bagaimanapun kondisinya. Berkaca dari hal tersebut pemerintah juga mengeluarkan kebijakan pembelajaran selama pandemi Covid-19 yang hampir semuanya memanfaatkan gawai dan perangkat komputer secara daring. Kendala yang dihadapi pada pembelajaran daring di berbagai daerah umumnya adalah sarana 
pembelajaran daring yang belum memadai, kurangnya pengalaman mengelola pembelajaran daring oleh guru, dan lingkungan belajar siswa yang kurang kondusif selama pandemi Covid19 (Zhang et al, 2020:6).

Oleh karena itu, guru-guru perlu menyesuaikan diri untuk dapat melaksanakan tugas pokok dan tanggung jawabnya sebagai pengajar. Penyesuaian tersebut dilakukan dengan melakukan praktik pembiasaan dalam mengelola pembelajaran secara daring. Namun, kemampuan masing-masing guru dalam mengelola kelas secara daring perlu ditelaah untuk memastikan Kegiatan Belajar Mengajar berjalan lancar. Hal ini umumnya dilakukan oleh kepala sekolah melalui kegiatan supervisi akademik secara terprogram. Supervisi akademik merupakan kegiatan kepala sekolah untuk membantu dan sekaligus mengawasi guru dalam rangka mengembangkan, memperbaiki, dan meningkatkan kualitas mengajar guru. Supervisi akademik dilaksanakan bertujuan memecahkan masalah pembelajaran melalui pembinaan guru agar lebih profesional. Supervisi akademik sangat penting dilaksanakan oleh kepala sekolah untuk mengetahui kinerja guru dan memperbaiki kekurangan yang ditemukan, termasuk kemampuan guru mengelola kelas secara daring (Rismawan, 2015:144).

Pada penelitian ini peneliti melaksanakan supervisi akademik menggunakan teknik supervisi kelompok. Selain dikarenakan subjek penelitian lebih dari satu orang guru, tenik supervisi kelompok dirasa lebih efektif dilakukan agar guru dapat saling bertukar pengalaman dalam melaksanakan kegiatan belajar mengajar dimasa pandemi covid-19 seperti sekarang ini. Tujuan penelitian ini yaitu: Untuk mengetahui supervisi akademik dapat meningkatkan kreativitas guru SMP Negeri 47 Kota Batam dalam melaksanakan Kegiatan Belajar Mengajar (KBM) di masa pandemi Covid-19 melalui pembelajaran daring pada semester I tahun pelajaran 2020/2021.

\section{METODE PENELITIAN}

Metode yang digunakan dalam penelitian ini adalah penelitian tindakan sekolah (PTS). Penelitian ini telah dilaksanakan pada semester I tahun pelajaran 2020/2021, lebih tepatnya mulai dari bulan Juli sampai dengan bulan Oktober 2020 di SMP Negeri 47 Kota Batam yang terletak dijalan raya Marina City Tj Uncang Kecamatan Batu Aji Kota Batam. Jumlah subyek yaitu 9 orang yang terdiri dari 3 guru laki-laki dan 6 guru perempuan. Metode yang dipakai untuk mengumpulkan data hasil penelitian ini adalah observasi. Metode ini digunakan untuk mengetahui kreativitas guru-guru melaksanakan proses pembelajaran daring.

Penelitian ini dilaksanakan dalam dua siklus. Setiap siklus dilakukan berdasar tahapan: (1) menyusun rencana kegiatan, (2) melaksanakan tindakan, (3) observasi, dan (4) analisis yang dilanjutkan dengan refleksi. Teknik Pengumpulan Data yang digunakan adalah teknik observasi dengan Instrumen Penelitian Kreativitas Guru dalam Melaksanakan Pembelajaran Daring dikembangkan sendiri oleh peneliti dengan mengadopsi pendapat Uno \& Nurdin (2012: 154156). Teknik Analisis Data yang digunakan dalam pelaksanaan penelitian tindakan, analisis data diwakili oleh momen refleksi. Refleksi yang dilakukan peneliti akan membantu dalam menafsirkan datanya. Data dalam penelitian ini dianalisis dengan analisis deskriptif kuantitatif, berupa rata-rata dan prosentase, serta pembandingan dengan indikator keberhasilan penelitian. Cara analisis tersebut adalah sesuai tuntutan statistik dasar bagi peneliti pemula yaitu mencari mean, median, modus, membuat interval kelas, penyajian dalam bentuk tabel dan grafik. Yang peneliti rencanakan ini hanya sebatas perhitungan yang mudah pada tingkat statistika dasar.

Indikator keberhasilan penelitian diperlukan sebagai acuan keberhasilan penelitian untuk menyatakan berakhirnya penelitian. Indikator tersebut adalah bahwa penelitian ini dianggap berhasil apabila baik pada siklus I maupun siklus II kreativitas guru-guru dalam melaksanakan kegiatan belajar mengajar melalui pembelajaran daring sudah mencapai nilai Amat Baik (A) dengan perolehan nilai antara 91 - 100 dengan ketuntasan minimal $85 \%$. 
Dari pelaksanaan tindakan baik dari awal, siklus I maupun siklus II menjadi diperoleh data hasil penelitian berupa data rekapitulasi kreativitas guru dalam melaksanakan pembelajaran daring, dimulai dari kondisi awal, kemudian siklus I dan dilanjutkan pula dengan siklus II.

Tabel 1. Rekapitulasi Hasil Penelitian

\begin{tabular}{|c|c|c|c|c|c|c|}
\hline \multirow{2}{*}{$\begin{array}{c}\text { Nomor Subjek } \\
\text { Penelitian }\end{array}$} & $\begin{array}{c}\text { Nuantitai } \\
\text { tif }\end{array}$ & $\begin{array}{c}\text { Kualitati } \\
\mathbf{f}\end{array}$ & $\begin{array}{c}\text { Kuantita } \\
\text { tif }\end{array}$ & $\begin{array}{c}\text { Kualitati } \\
\text { f }\end{array}$ & $\begin{array}{c}\text { Kuantita } \\
\text { tif }\end{array}$ & $\begin{array}{c}\text { Kualitati } \\
\text { f }\end{array}$ \\
\hline 1 & 92 & $\mathrm{~A}$ & 96 & $\mathrm{~A}$ & 98 & $\mathrm{~A}$ \\
\hline 2 & 92 & $\mathrm{~A}$ & 94 & $\mathrm{~A}$ & 96 & $\mathrm{~A}$ \\
\hline 3 & 68 & $\mathrm{C}$ & 78 & $\mathrm{~B}$ & 92 & $\mathrm{~A}$ \\
\hline 4 & 76 & $\mathrm{~B}$ & 92 & $\mathrm{~A}$ & 96 & $\mathrm{~A}$ \\
\hline 5 & 70 & $\mathrm{C}$ & 78 & $\mathrm{~B}$ & 92 & $\mathrm{~A}$ \\
\hline 6 & 72 & $\mathrm{C}$ & 80 & $\mathrm{~B}$ & 94 & $\mathrm{~A}$ \\
\hline 7 & 64 & $\mathrm{C}$ & 70 & $\mathrm{C}$ & 84 & $\mathrm{~B}$ \\
\hline 8 & 66 & $\mathrm{C}$ & 76 & $\mathrm{~B}$ & 92 & $\mathrm{~A}$ \\
\hline 9 & 74 & $\mathrm{C}$ & 92 & $\mathrm{~A}$ & 96 & $\mathrm{~A}$ \\
\hline & & & & & & \\
\hline Jumlah Nilai & $\mathbf{6 7 4}$ & & $\mathbf{7 5 6}$ & & $\mathbf{8 4 0}$ & \\
\hline Nilai Rata-rata & $\mathbf{7 4 , 8 9}$ & $\mathrm{C}$ & $\mathbf{8 4}$ & $\mathrm{B}$ & $\mathbf{9 3 , 3 3}$ & $\mathrm{A}$ \\
\hline Guru yang tuntas & $\mathbf{2}$ & & $\mathbf{4}$ & & $\mathbf{8}$ & \\
\hline Guru yang belum tuntas & $\mathbf{7}$ & & $\mathbf{5}$ & & $\mathbf{1}$ & \\
\hline Prosentase ketuntasan & $\mathbf{2 2 , 2 2}$ & & $\mathbf{4 4 , 4 4}$ & & $\mathbf{8 8 , 8 9}$ & \\
\hline & $\mathbf{\%}$ & & $\mathbf{\%}$ & & $\mathbf{\%}$ & \\
\hline
\end{tabular}

Pada masa pandemi Covid-19 ini guru dituntut untuk memiliki kreativitas yang tinggi dalam melaksanakan pembelajaran. Guru yang terbiasa melaksanakan pembelajaran secara tatap muka, dimasa pandemi ini harus mampu melaksanakannya secara daring. Meskipun ini merupakan hal yang baru bagi guru, namun guru diharapkan mampu secara kreatif mengemas pembelajaran semenarik mungkin agar materi tersampaikan dengan baik dan siswa tetap memiliki semangat belajar yang tinggi meskipun harus dilaksanakan secara jarak jauh.

Pada kondisi awal terlihat bahwa kreativitas guru dalam melaksanakan pembelajaran daring masih tergolong rendah. Terlihat dari perolehan rata-rata hasil observasi yang dilakukan yaitu hanya mencapai 74,89 (kategori C) dengan prosentase ketuntasan baru mencapai 22,22\%. Hal ini dikarenakan terdapat kelemahan-kelemahan pada diri guru yaitu 1) guru masih gagap teknologi dikarenakan rasa ingin tahu guru yang masih rendah terhadap kemajuan teknologi yang ada, 2), guru masih berpatokan pada cara pembelajaran konvensional dan tidak mau terbuka terhadap pengalaman baru, 3) guru masih kesulitan dalam memilih dan menggunakan aplikasi yang tepat dalam pembelajaran daring dikarenakan belum memiliki pemahaman yang baik terhadap aplikasi-aplikasi baru, 4) Guru kesulitan menyajikan materi pelajaran melalui pembelajaran daring dikarenakan terbiasa melaksanakan pembelajaran dengan berceramah tatap muka, 5) Guru kesulitan mengatasi kendala-kendala yang disebabkan oleh jaringan dikarenakan pemahaman guru masih terbatas.

Rendahnya kreativitas guru dalam melaksanakan pembelajaran daring menyebabkan peneliti selaku kepala sekolah merasa harus melakukan upaya-upaya untuk meningkatkan kreativitas guru demi kualitas pembelajaran siswa-siswa di SMP Negeri 47 Kota Batam. Untuk itu peneliti berdiskusi dengan teman sejawat maupun guru senior dan pengawas sekolah serta 
membaca berbagai sumber teori dan pendapat ahli, sehingga peneliti memilih untuk mengupayakan supervisi akademik guna meningkatkan kreativitas guru.

Pada pelaksaan tindakan siklus I perencanaan telah diupayakan dengan baik, instrumen yang digunakan sejak awal telah divalidasi oleh guru senior, pelaksanaan tindakan telah berlangsung dengan baik dengan pemberian bimbingan serta arahan. Peneliti mengajak guru berdiskusi mengenai proses pembelajaran daring yang telah dilakukan, kemudian memaparkan hasil observasi awal pada guru dan menjabarkan kelemahan-kelemahan serta penyebab permasalahan. Selanjutnya peneliti memberikan penjelasan mengenai tindakan supervisi akademik yang akan dilakukan dan dimulai dengan menentukan tujuan atau sasaran yang hendak dicapai, dilanjutkan dengan memberikan arahan, bimbingan dan pembinaan mengenai alat dan media yang diperlukan berikut dengan cara penggunaan yang tepat serta bagaimana cara melaksanakan proses pembelajaran daring yang sesuai dengan yang diharapkan. Kemudian berlanjut pada kegiatan observasi yang mana guru melaksanakan proses pembelajaran daring dan peneliti melakukan pengawasan serta penilaian dengan mengisi lembar observasi.

Perolehan rata-rata pada siklus I sebesar 84 (kategori B) dengan prosentase ketuntasan 44,44\%. Ini menunjukkan bahwa telah terjadi peningkatan pada kreativitas guru dalam melaksanakan proses pembelajaran daring yang sebelumnya masih berada pada kategori C. Meskipun sudah terjadi peningkatan, namun hasil yang diperoleh dengan kegiatan tindakan yang sudah giat dilakukan ternyata belum sesuai harapan. Ini dikarenakan hasil yang diperoleh belum sesuai dengan harapan indikator keberhasilan penelitian yang dicanangkan yaitu minimal $85 \%$ guru berhasil. Data tersebut menunjukkan bahwa kreativitas guru dalam melaksanakan pembelajaran daring belum maksimal, sehingga penelitian harus dilanjutkan ke siklus berikutnya dan peneliti harus lebih giat lagi mengatasi kelemahan-kelemahan yang masih tersisa. Adapun kelemahan-kelemahan yang tersisa antara lain: 1) guru masih kesulitan dalam memilih dan menggunakan aplikasi yang tepat dalam pembelajaran daring dikarenakan terlalu banyak pilihan aplikasi-aplikasi baru yang dipelajari, 2) guru masih kesulitan menyajikan materi pelajaran melalui pembelajaran daring. Hal ini terlihat dari kurang bervariasinya cara penyajian materi yang dilakukan oleh guru dan cenderung menyuruh siswa membaca buku saja, 3) guru kesulitan mengatasi kendala-kendala yang disebabkan oleh jaringan dikarenakan pemahaman guru masih terbatas, 4) Guru belum terlihat memberikan penguatan pada siswa atas tugas-tugas yang telah dilaksanakan.

Selanjutnya pada siklus II ini semua kelemahan yang masih tersisa pada siklus I diperhatikan dengan baik dan dilakukan inovasi-inovasi yang lebih maksimal agar hasil yang diperoleh sesuai harapan tujuan penelitian ini. Guru-guru diajak berdiskusi mengenai kelebihan atau perubahan positif yang sudah terlihat pada guru serta mendiskusikan juga kelemahankelemahan guru yang masih tersisa guna lebih meningkatkan kreativitas guru. Guru diajak bertanya jawab tentang penyebab-penyebab kekurangan yang ada, mengajak mereka berdiskusi, bertukar pikiran tentang apa yang mesti dilakukan pada saat melaksanakan proses pembelajaran daring untuk mengatasi kekurangan-kekurangan yang ada pada siklus I. Selanjutnya guru yang memiliki pemahaman lebih baik diminta untuk membantu menjelaskan lebih rinci mengenai penggunaan aplikasi penunjang pembelajaran daring yang belum dipahami guru lainnya. Tidak lupa media pembelajaran yang telah dibuat oleh guru seperti video, gambar, serta link yang dapat membantu penyampaian materi pelajaran dijadikan contoh untuk merangsang kreativitas guru-guru lainnya dalam menyiapkan media pembelajaran yang bervariasi. Peneliti juga memberikan pemahaman kepada guru pentingnya pemberian penguatan pada siswa atas tugas yang telah berhasil mereka kerjakan.

Dari semua tindakan yang sudah dilakukan pada siklus II ini ternyata hasil yang diperoleh sudah melebihi tuntutan indikator keberhasilan penelitian yaitu prosentase yang diperoleh sudah mencapai 88,89\% dengan rata-rata mencapai 93,33 berarti sudah termasuk dalam kategori A. Hasil ini tentu diperoleh akibat kerja keras yang dilakukan. Dengan hasil tersebut penelitian sudah dianggap berhasil dan tidak diteruskan ke siklus berikutnya. Untuk 
mempermudah membaca peningkatan yang terjadi, maka berikut penulis sajikan dalam bentuk grafik garis.

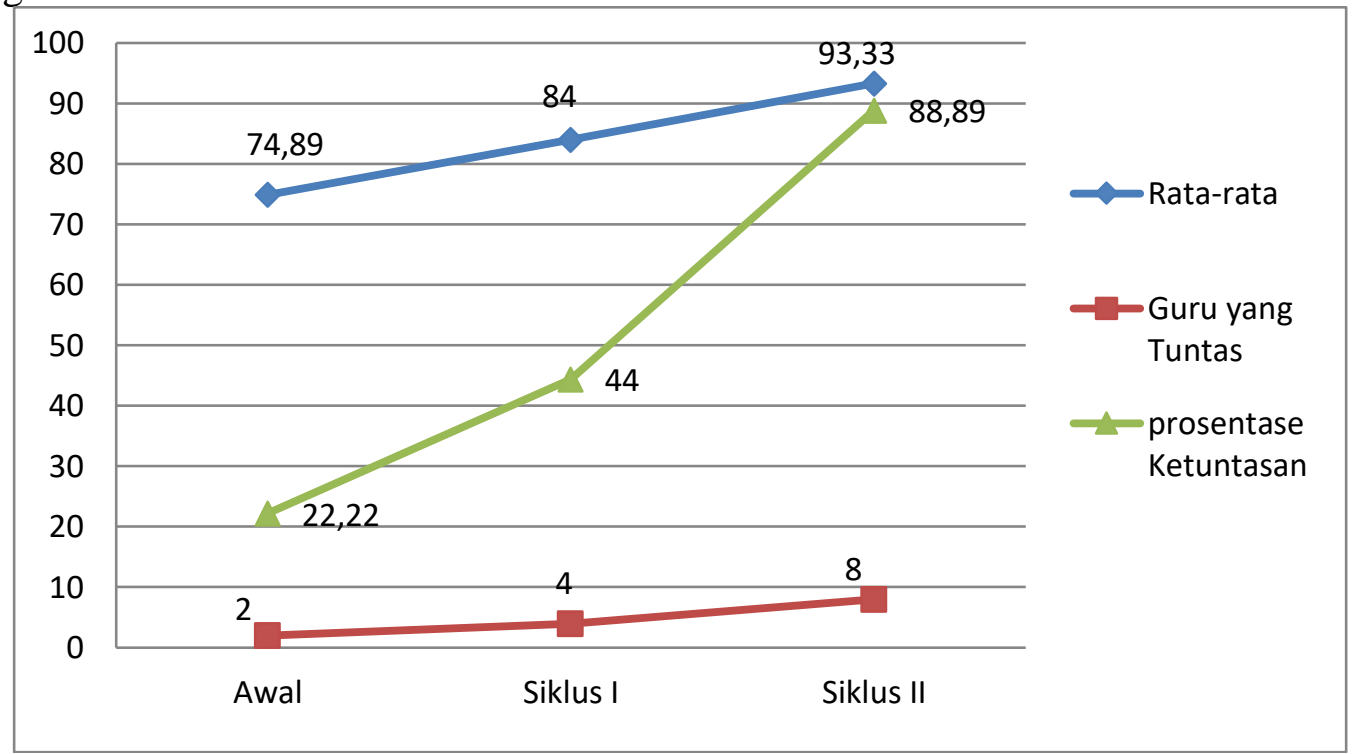

Gambar 1. Grafik garis Rekapitulasi Hasil Penelitian.

Supervisi akademik dapat meningkatkan kreativitas guru dalam melaksanakan kegiatan belajar mengajar (KBM) di masa pandemi covid-19 melalui pembelajaran daring pada semester I Tahun pelajaran 2020/2021 Di SMP Negeri 47 Kota Batam karena supervisi akademik menurut Djam'an Satori, 1989 (dalam Syarif, 2012:89) supervisi akademik adalah upaya-upaya yang sifatnya memberikan kesempatan pada guru-guru berkembang secara profesional. Dapat dikatakan bahwa supervisi akademik merupakan kegiatan-kegiatan yang menciptakan kondisi yang layak bagi pertumbuhan profesional guru-guru secara terus-menerus. Kegiatan supervisi memungkinkan guru-guru memperoleh arah diri dan belajar memecahkan sendiri problem yg dihadapi pembelajaran dengan imajinatif, penuh inisiatif dan kreativitas, bukan konformitas. Sedangkan menurut Daresh 1989 (dalam Martiyono, 2014:99) supervisi akademik adalah serangkaian kegiatan untuk membantu guru mengembangkan kemampuannya mengelola proses pembelajaran demi pencapaian tujuan pembelajaran. Supervisi akademik merupakan upaya membantu guru-guru mengembangkan kemampuannya mencapai tujuan pembelajaran.

Selain itu hasil penelitian ilmiah Sulistyani (2021: 48) menunjukan Rerata keseluruhan hasil supervisi akademik sebelum pandemi Covid-19 (Prasiklus) sebesar 82,06\%. Rerata keseluruhan hasil supervisi akademik pada masa pandemi Covid-19 di semester genap tahun pelajaran 2019/2020 (Siklus I) turun menjadi 77,67\%. Rerata keseluruhan hasil supervisi akademik pada masa pandemi Covid-19 di semester gasal tahun pelajaran 2020/2021 (Siklus II) naik menjadi $80,72 \%$. Dengan demikian, penguatan dan pelatihan mengelola pembelajaran daring mampu meningkatkan kinerja guru selama pandemi Covid-19 tahun 2020. Sedangkan hasil penelitian Purpuniyanti, \& Dwikurnaningsih,(2021:27). Dengan adanya pelaksanaan supervisi yang tetap dilakukan di masa pandemi Covid-19 meningkatkan kreatifitas guru dalam melaksanakan pembelajaran PJJ. Dengan adanya model pembelajaran yang lebih kreatif meningkatkan motivasi/semangat peserta didik mengikuti PJJ. Dengan semakin aktifnya peserta didik dalam mengikuti kegiatan pembelajaran maka nilai/prestasi peserta didik semakin meningkat.

\section{KESIMPULAN}

Berdasarkan analisis yang telah dilakukan dan pembahasan yang telah disampaikan, menggambarkan dengan jelas bahwa penerapan supervisi akademik yang telah diupayakan terhadap guru-guru SMP Negeri 47 Kota Batam telah berjalan dengan baik dan lancar. Setelah dilakukan refleksi ternyata hasil yang diperoleh adalah kreativitas guru dalam melaksanakan 
pembelajaran daring telah meningkat dari rata-rata awal 74,89 (kategori C) meningkat menjadi 84 (kategori B) pada siklus I dan meningkat menjadi 93,33 (kategori A) pada siklus II. Prosentase ketuntasan yang diperoleh juga mengalami peningkatan dari awalnya 22,22\%, meningkat menjadi $44,44 \%$ pada siklus I dan meningkat lagi menjadi $88,89 \%$ pada siklus II. Data tersebut membuktikan bahwa rumusan masalah dan tujuan penelitian ini telah terjawab serta hipotesis yang diajukan sudah dapat dibuktikan kebenarannya.

Oleh karena itu simpulan yang dapat disampaikan adalah supervisi akademik yang diupayakan secara maksimal dapat meningkatkan kreativitas guru SMP Negeri 47 Kota Batam dalam melaksanakan Kegiatan Belajar Mengajar (KBM) di masa pandemi Covid-19 melalui pembelajaran daring pada semester I tahun pelajaran 2020/2021.

\section{DAFTAR PUSTAKA}

Anugrahana, A. (2020). Hambatan, Solusi dan Harapan: Pembelajaran Daring Selama Masa Pandemi Covid-19 Oleh Guru Sekolah Dasar. Scholaria: Jurnal Pendidikan dan Kebudayaan, 10 (3), 282-289.

Depdiknas. (2009). Penelitian Tindakan Sekolah. Jakarta: Dirjen PMPTK

Indayani, Retno. (2002). Kreatifitas Guru dalam Proses Pembelajaran. Tulungagung: STAIN Tulungagung.

Martiyono. (2014). Mengelola dan Mendampingi Implementasi Kurikulum 2013. Yogyakarta: Aswaja.

Martiyono. (2014). Mengelola dan Mendampingi Implementasi Kurikulum 2013. Yogyakarta: Aswaja.

Ngainun. (2009). Menjadi Guru Inspiratif. Yogyakarta: Pustaka Belajar.

Purpuniyanti, \& Dwikurnaningsih, (2021). Supervisi Akademik Dengan Aplikasi Google Form Untuk Peningkatan Kreativitas Guru Dalam Pelaksanaan PJJ. https://prosiding.iahntp.ac.id

Rismawan, E. (2015). Pengaruh Supervisi Kepala Sekolah dan Motivasi Berprestasi Guru terhadap Kinerja Mengajar Guru. Jurnal Administrasi Pendidikan, 22 (1), 114-132.

Sadikin, Ali. (2020). Pembelajaran Daring di Tengah Wabah Covid-19. Jambi: Jurnal Ilmiah Pendidikan Biologi FKIP Universitas Jambi. Tersedia di https://onlinejournal.inja.ac.id/biodik

Sulistityani. (2021). Supervisi Akademik Kepala Sekolah Dasar untuk Meningkatkan Kinerja Guru di Masa Pandemi Covid-19 (Studi Kasus di SD 1 Prambatan Kidul Kudus Tahun 2020). Jurnal Media Penelitian Pendidikan: Jurnal Penelitian dalam Bidang Pendidikan dan Pengajaran. Vol. 15, No. 1, Juni 2021, pp. 37-49. Tersedia di DOI: http://dx.doi.org/10.26877/mpp.v15i1.8384

Surat Edaran Nomor 4 Tahun 2020 Tentang Pelaksanaan Kebijakan Pendidikan Dalam Masa Darurat Penyebaran COVID-19

Syaodih, Nana Sukmadinata. (2009). Landasan Psikologi Proses Pendidikan. Bandung: PT Remaja Rosdakarya.

Syarief, Akhmad. (2012). Etika Profesi Pendidikan. Yogyakarta: LaksBang Pressindo.

Uno, B. Hamzah \& Nurdin Mohamad. (2012). Belajar dengan Pendekatan PAILKEM: Pembelajaran Aktif, Inovatif, Lingkungan, Kreatif, Efektif, Menarik, cet. Iii. Jakarta: PT Bumi Aksara.

Zhang, W., Wang, Y., Yang, L., dan Wang, C. (2020). Suspending Classes Without Stopping Learning : China's Education Emergency Management Policy in the COVID-19 Outbreak. Journal of Risk and Financial Management, 13 (55), 1-6. 